\title{
Structural Characterisation of the Leaf of Bauhinia monandra Kurz (Fabaceae - Cercidoideae)
}

\author{
Mariana Novais Antunes ${ }^{1}$ \\ https://orcid.org/0000-0002-4651-7916 \\ Fabiano Rodrigues Pereira ${ }^{1}$ \\ https://orcid.org/0000-0001-5357-118X
}

\section{Carlos André Espolador Leitão ${ }^{2 *}$ \\ https://orcid.org/0000-0002-1988-7436}

${ }^{1}$ State University of Southwest Bahia , Undergraduate student of Forest Engineering, Vitória da Conquista, Bahia, Brazil;

${ }^{2}$ State University of Southwest Bahia, Department of Natural Sciences, Vitória da Conquista, Bahia, Brazil.

Editor-in-Chief: Paulo Vitor Farago

Associate Editor: Jane Manfron Budel

Received: 2020.09.24; Accepted: 2021.04.07.

*Correspondence: candreel@yahoo.com.br; Tel.: +55-77-3425-9323 (C.A.E.L.)

\section{HIGHLIGHTS}

- Bauhinia monandra leaf is mesomorphous to xeromorphous.

- It has glandular navicular and uniseriate nonglandular trichomes.

- The petiole has differential anatomical characteristics within the genus.

- The pulvinus and the motile cushion have live pectic septate fibres.

Abstract: Bauhinia monandra Kurz (Fabaceae) is an ornamental leguminous tree from Africa. Its leaf has been proven to be hypoglycaemic, and are a source of lecithin BmoLL, providing this species with great medicinal potential. Curiously, there are no reports of the anatomical description of the leaf of this species. The present work aimed at describing the leaf anatomy of $B$. monandra, and make histochemical inferences. To this end, anatomical procedures in light and scanning electron microscopy were performed from different parts of the leaves of plants growing in the state of Bahia, Brazil. The leaf is amphistomatous. It possesses papillate epidermis, nonglandular and navicular trichomes, and the mesophyll is dorsiventral. The central vein is distinct from the others of the first degree. The first, second, and third-degree veins possess thick fibre bundles with associated monocrystals. The other veins are a little fibrous and excessively reduced. The petiole vascularisation consists of circularly arranged collateral bundles, plus two accessory bundles. The pulvinus have a wide parenchymatic cortex with abundant druses and vascularisation restricted to the central region, surrounded by a crystalline sheath and by a starch sheath. The motile cushion has the vascular bundles arranged in series. Associated with the phloem from the pulvinus vascular bundles and the motile apparatus, occur non-lignified septate fibres that confer flexibility to these organs. The absence of lateral projections and the arrangement of vascular bundles in the petiole was the most distinctive anatomical features and of the greatest taxonomic potential observed in the leaf of $B$. monandra. 
Keywords: leaf anatomy; lecithin; leguminous; medicinal plant; ornamental tree.

\section{INTRODUCTION}

Bauhinia L. is by far the largest genus of Cercidoideae (Fabaceae) [1]. With about 300 species [2], Bauhinia has characteristic palminervous bilobed or bifoliate leaves, with an apical extension between the lobes or leaflets. The petiole has two thickenings, named proximal and distal pulvinus. At the base of the leaf blade, there is a joint called motile cushion, responsible for the distinctive nyctinastic movements of opening and closing the limbus [3]. The genus Bauhinia has several species of medicinal importance, mainly hypoglycemic, such as B. divaricata [4], B. forficata [5], B. megalandra [6], and B. monandra [7].

Bauhinia monandra Kurz is an African tree [8]. Despite its tropical origin, it adapts well to regions of amene climate. In Brazil, it is often grown in the North and Northeast regions, being rare in the South region of the country. This species is evergreen, 5-7 meters tall, and produces large pink flowers. As a markable and distinctive morphological characteristic, its flowers have a single fertile stamen [9], which is why it received the specific epithet monandra.

It is an ornamental tree [10] used in urban arborisation [11-13]. Lately, $B$. monandra has been intensively investigated as to its importance for man. Its seeds are potential sources of biodiesel [14] and amino acids for animal feeding, including humans [15]. The leaves are widely used in folk medicine, mainly in the treatment of diabetes. Its anti-glycaemic properties, stimulating the release of insulin in the blood, have been confirmed in rodents $[7,16]$. They also have antimicrobial activity, being a safe and economical alternative for treating infectious diseases [17]. The leaves are a source of antioxidant steroids and flavonoids [18-20] and of lecithin BmoLL, which has an anti-inflammatory and anti-nociceptive action tested in mice [21] and also, insecticidal action duly confirmed [22].

Some species of the genus had their leaf anatomy described, such as $B$. blakeana [23, 24], $B$. cheilantha [25], B. curvula [26], B. forficata [27-29], B. malabarica [24], B. microstachya [30], B. pentandra [25], B. purpurea, $B$. racemosa, $B$. tomentosa [24, 31], $B$. ungulata [25], and $B$. variegata [29,31]. With this information, it is possible to use a larger amount of parameters, thus giving greater robustness in taxonomic discussions. Anatomical characteristics are of great value in the resolution of phylogenetic relationships [32], and leaf structure aspects are useful even for the development of dichotomous keys to distinguish species [33].

As for the B. monandra, despite the great importance and extensive studies carried out on this species, little is known about its anatomy. The leaves, which are of great potential for several applications, do not even have their surface and internal structure satisfactorily described. Knowledge on the leaf structure of $B$. monandra is of basal importance for taxonomic, physiological and pharmacological studies. Also, for the quality control of commercialised phytopharmaceuticals [34], mainly to avoid counterfeiting [35]. It has recently been demonstrated that the pattern of leaf blade veins is a valuable tool for distinguishing several species of Bauhinia commercialized for medicinal purposes, although in this study the leaves of $B$. monandra were not analysed [36]. A more detailed analysis of different parts of the leaf would certainly contribute even more to the efficiency of this quality control. Thus, the present study aimed to describe the leaf anatomy of $B$. monandra and, using the Toluidine blue $\mathrm{O}$ dye in $\mathrm{pH} 4.0$ [37] among other usual techniques in plant anatomy, to obtain a greater wealth of information from the analysed cells and tissues [38] for taxonomic, physiological and pharmacological purposes.

\section{MATERIAL AND METHODS}

Three adult individuals of $B$. monandra growing at the Universidade Estadual do Sudoeste da Bahia, Campus of Vitória da Conquista, Bahia State, Brazil, at the coordinates $14^{\circ} 53^{\prime} 28^{\prime \prime} \mathrm{S}, 40^{\circ} 48^{\prime} 144^{\prime \prime}$, and at 823 meters above sea level, were studied. The vouchers were deposited at the UESC Herbarium under the numbers 21.964, 21.965 and 21.966.

Fully expanded, whole and healthy leaves, with the leaf blade measuring $11-13 \mathrm{~cm}$ in length, were obtained from the fifth to the eighteenth nodes, from 2017 August to 2018 May. These leaves were preliminarily examined using a Motic SMZ-143-FBLED stereoscopic equipped with a Canon PowerShot SD3500 digital camera for observation and photographic documentation. With the aid of a razor blade, samples from different parts of the leaf were isolated, namely: the petiole, segments of the proximal pulvinus, the middle part of the petiole and the distal pulvinus. From the leaf blade, the motile cushion, mesophyll, veins of all degrees and foliar edge were isolated. 


\section{Light microscopy}

Part of the samples was immediately sectioned, obtaining numerous cross and longitudinal-sections. Paradermal-sections were also performed on both sides of the leaf blade. These sections were made by freehand with the aid of a razor blade [39] and observed in fresh with and without staining. For staining, obtaining metachromasia and histochemical inferences, Toluidine blue $\mathrm{O} 0.025 \%$ was used in Mcllvaine buffer at $\mathrm{pH}$ $4.0[37,38,40]$ for $15 \mathrm{~min}$. For starch identification, the Lugol test [41] was performed. After staining, the sections were washed in distilled water and the slides were mounted with coverslips and distilled water [42].

For analysis and photographic documentation, a Leica DM750 light microscope equipped with an ICC50 HD (Leica) digital image capture system (Leica Microsystems, Wetzlar, Germany) was used. The anatomical description was performed according to the terminological criteria of Metcalfe and Chalk [43] and Wilkinson [44]. At least 30 sections per leaf part were analysed. Each individual had at least five leaves analysed.

\section{Scanning electron microscopy}

Samples of blades of five leaves from each of the three individuals studied were fixed in a solution containing $0.5 \%$ glutaraldehyde, $4 \%$ paraformaldehyde, $3 \%$ sucrose and $5 \mathrm{mmol} / \mathrm{L}$ calcium chloride in 0.2 $\mathrm{mol} / \mathrm{L}$ phosphate buffer at $\mathrm{pH} 7.2$ [45] for $24 \mathrm{~h}$ at $6{ }^{\circ} \mathrm{C}$, then washed in the same buffer, dehydrated in an ethanolic series and submitted to the $\mathrm{CO}_{2}$ critical point using a Bal-tec CPD030 (Balzers, Schaan, Liechtenstein). The samples were adhered to stubs and subjected to cathodic gold sputtering in a Bal-tec SCD050 (Balzers, Schaan, Liechtenstein) sputter coater [46]. The observations and electron micrographs acquisition were performed in a Quanta 250 (FEI Company, Oregon, USA) scanning electron microscope at $10 \mathrm{Kv}$, equipped with a digital image acquiring system.

\section{RESULTS}

\section{Leaf blade}

The epidermis is single-layered and papillate, with epicuticular waxes in a plate pattern (Figure $1 \mathrm{~A}, \mathrm{~B}$ ). In paradermal-section, the ordinary cells have sinuous to straight anticlinal walls on the adaxial side (Figure $1 \mathrm{C}, \mathrm{D})$ and straight on the abaxial one (Figure $1 \mathrm{E}$ ). There are normal uniseriate multicellular nonglandular trichomes with verrucous ornamentation on both sides (Figure $1 \mathrm{~B}, \mathrm{~F}$ ), mainly on the veins, where these trichomes are longer (Figure $1 \mathrm{G}$ ). Normal, multiseriate multicellular glandular trichomes (navicular trichomes) are present only on the abaxial surface, being more numerous on the edge and the veins, mainly in the vicinity of the motile cushion (Figure $1 \mathrm{H}$ ). The stomata are of the paracytic and anomocytic type, located at the same level as ordinary cells and occurring basically in the abaxial epidermis (Figure $1 \mathrm{E}$ ). In the adaxial epidermis, stomata are scarce, restricted to the vicinity of the first-degree veins and are rudimentary (Figure $1 \mathrm{D})$.

The mesophyll is dorsiventral, with two layers of palisade parenchyma that represent about $3 / 4$ of the mesophyll thickness, and about two layer of spongy parenchyma, whose cells are shorter and tending to braciform (Figure $1 \mathrm{I}$ ). Some mesophyll cells contain druse (Figure $1 \mathrm{I}, \mathrm{J}$ ), other few accumulate material that stains blue with Toluidine blue $\mathrm{O}$ at $\mathrm{pH} 4.0$ (TBO) (Figure $1 \mathrm{~K}$ ). The leaf edge is enlarged and has one to three layers of cells that appear to be a hypodermis, where some cells can also accumulate material that stains blue with TBO. In cross-section, the vascular bundle present in the leaf edge is characterised by its outline more circular (Figure $1 \mathrm{~K}, \mathrm{~L}$ ), by a large number of fibres, mainly associated with phloem, and by the small relative size of the xylem (Figure $1 \mathrm{M}$ ), in comparison to the other vascular bundles of the mesophyll, which are described below. 

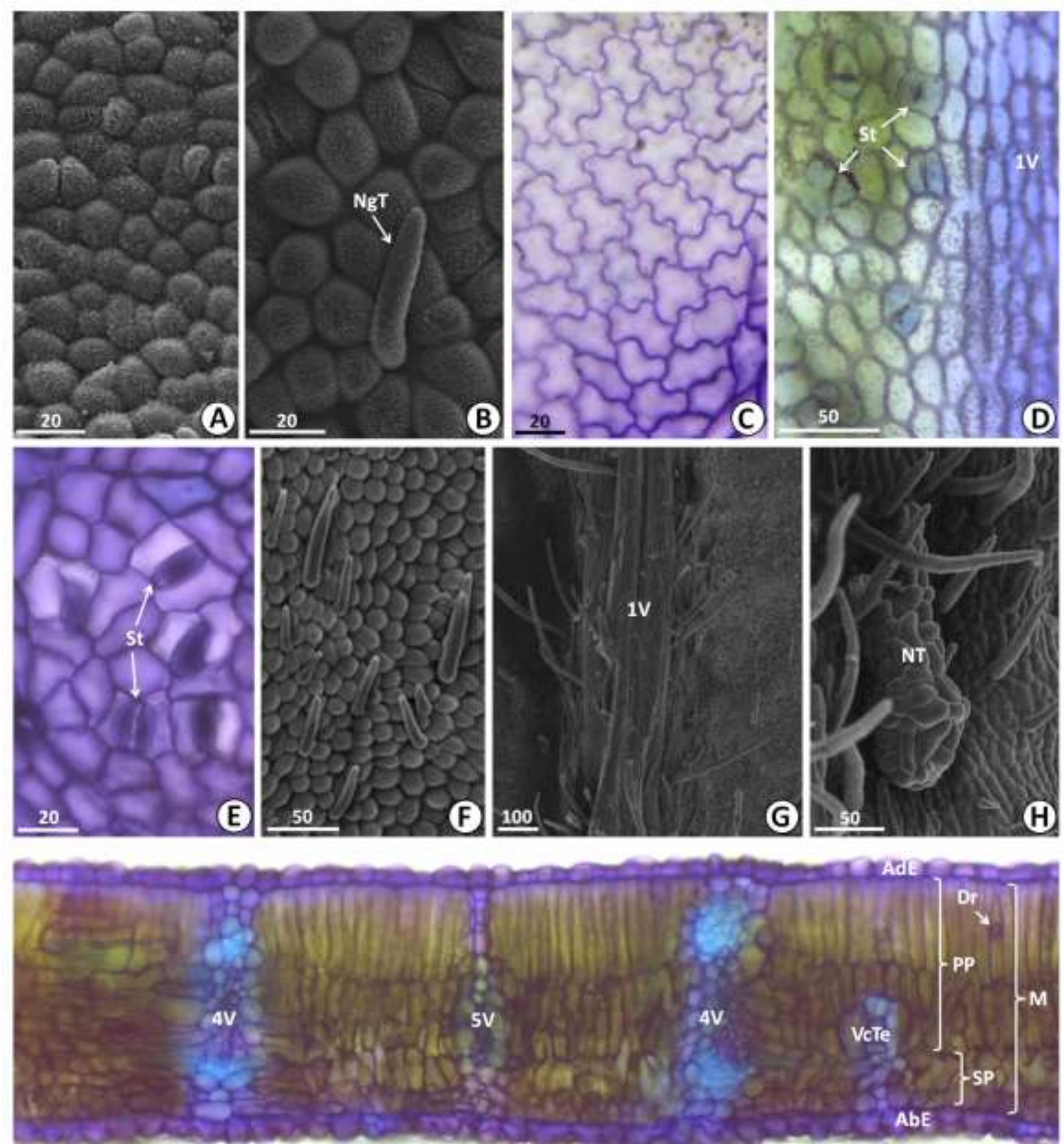

50

(1)
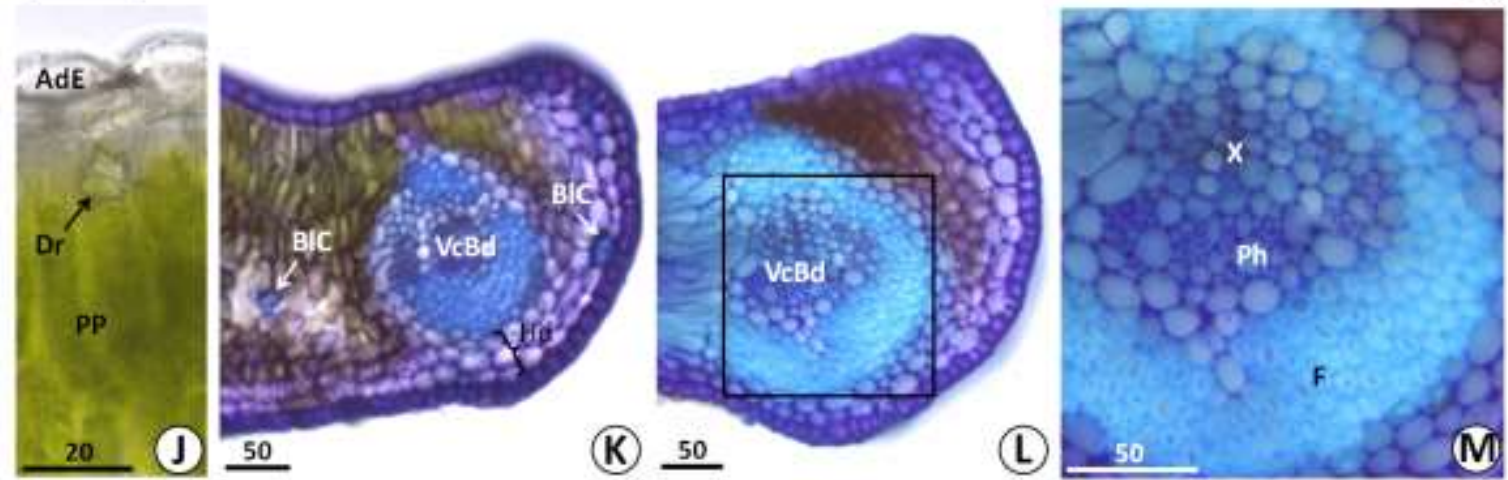

Figure 1. Micrographs of the Bauhinia monandra leaf blade. Scanning electron microscopy (A, B, F-H), paradermal (CE) and cross-sections (I-M) stained with Toluidine blue $O(C-E, I, K-M)$ and not stained (J). A. Adaxial epidermis. B. Abaxial epidermis. C, D. Adaxial epidermis. E-H. Abaxial epidermis. I. Mesophyll, showing the epidermis, chlorenchyma and vascularization. J. Detail of the palisade parenchyma, showing a druse. K, L. Leaf edge. M. Detail of the region delimited by the square in L. Legends: $1 \mathrm{~V}$ - first-degree vein; $4 \mathrm{~V}$ - fourth-degree vein; $5 \mathrm{~V}$ - fifth-degree vein; AbE- abaxial epidermis; AdE- adaxial epidermis; BIC- blue stained cell; Dr- druse; F- fibres; Hd- hypodermis; M- mesophyll; NgTnonglandular trichome; NT- navicular trichome; PP- palisade parenchyma; Ph- phloem; SP- spongy parenchyma; Ststomata; VcBd- vascular bundle; VcTe- vascular termination; X-xylem. Scale bars are in micrometres. 
The central vein is very different from the other first-degree veins (Figure $2 \mathrm{~A}$ ). It is characterised by an almost complete circular projection towards the adaxial side (Figure $2 \mathrm{~B}$ ). The adaxial epidermis is wrinkled forming a groove, subtended by circa of two annular collenchyma layers. Subjacent, there is a vascular bundle with a group of fibres which stained in greenish-blue with TBO, dorsal to the xylem (Figure $2 \mathrm{C}$ ), and an arched sheath of similar fibres surrounding the phloem (Figure $2 \mathrm{~B}$ ). In the latter, idioblasts that also stain in greenish-blue with TBO may occur (Figure $2 \mathrm{E}$ ). On the abaxial side, there are two layers of collenchyma subjacent to the epidermis. Internally, collapsed cells occur and, subjacent, two layers of ground parenchyma. Finally, there is the fibre sheath whose walls also were coloured in greenish-blue (Figure $2 \mathrm{E}$ ). The leaf blade is thinner in the vicinity of the central vein, where the mesophyll consists of two layers of isodiametric cells of chlorenchyma (Figure $2 \mathrm{D}$ ).

The other first-degree veins (Figure $2 \mathrm{~A}, \mathrm{~F}$ ), excluding the central one, are also conspicuously protruding from the abaxial side, but slightly protruding from the adaxial side (Figure $2 \mathrm{G}$ ). Also, they are thicker and less circular in cross-section than the central vein. There is a narrow band of collenchyma that is larger than that of the central vein, which extends from the adaxial epidermis to one fibre bundle (Figure $2 \mathrm{H}$ ). This bundle is found at the dorsal portion of a large arc-shaped vascular bundle, in contact with the xylem parenchymal cells. Associated with the phloem, there are fibres organised in an arc that surrounds the vascular bundle in its ventral portion (Figure $2 \mathrm{G}$ ). The outermost fibres may be associated with prismatic crystals. Externally surrounding this arc of fibres, there are circa of two layers of ground parenchyma. In the apical region of the veins protrusions, on the abaxial face, there is a parenchyma transitional to collenchyma with collapsed aspect, forming rugosities on its surface. External to the collapsed layer, there is a collenchyma layer and, finally, the epidermis (Figure $2 \mathrm{I}$ ).

The second-degree veins (Figure $2 \mathrm{~A}, \mathrm{~F}$ ) have a similar structure to the first-degree ones, differing basically by their smaller size, the collenchyma underlying the abaxial as well as the collapsed parenchymatic cells are absent and, consequently, there are no rugosities on the abaxial side (Figure $3 \mathrm{~A}$ ).

The third-degree veins (Figure $2 \mathrm{~F}$ ) are not very prominent on both sides. They consist of a vascular bundle with fibre clusters associated with the xylem and phloem. When viewed in cross-section, these fibres have an arrangement tending to elliptical in the xylem and an arc arrangement in the phloem. The vascular bundle is surrounded by a sheath that makes indirect contact with the epidermis by a narrow strip of a single layer of hypodermic cells, on both sides (Figure $3 \mathrm{~B}$ ).

The fourth-degree veins (Figures $1 \mathrm{I}, 2 \mathrm{~F}$ ) do not protrude on either side. The vascular bundle is very small. The sheath extends from epidermis to epidermis, and the fibres occur in small numbers in each pole of these vascular bundles (Figure $3 \mathrm{C}$ ). The fifth-degree veins (Figures $1 \mathrm{I}, 2 \mathrm{~F}$ ) are structurally similar to the fourth-degree ones, however, they are even narrower with less vascular tissues and may not have fibres (Figure $3 \mathrm{D}$ ). Finally, the vascular terminations in the centre of the areoles (Figure $2 \mathrm{~F}$ ) occur in the abaxial half of the mesophyll (Figure $1 \mathrm{I}$ ), they are constituted only by xylem surrounded by a sheath that extends merely to the abaxial epidermis (Figure $3 \mathrm{E}$ ).

In the motile cushion (Figures $2 \mathrm{~A}, 3 \mathrm{~F}$ ), the epidermis is characterised by its wrinkled appearance, with longitudinal creases on both sides (Figure $3 \mathrm{G}, \mathrm{H}$ ). Both epidermises are single-layered (Figure $3 \mathrm{I}$ ). There are no stomata and dense trichomes occur on the abaxial side (Figure $3 \mathrm{H}$ ). The cortex is broad (Figure $3 \mathrm{~F}$ ), with thick parenchyma, and there are also numerous druse idioblasts (Figure $3 \mathrm{I}$ ). In the vicinity of the five to six vascular bundles that go to the first order veins of each leaf blade lobe, the parenchyma tends to chlorenchyma. These vascular bundles (Figure $3 \mathrm{~J}$ ) occur in a linear arrangement (Figure $3 \mathrm{~F}$ ). They are surrounded by a starch sheath (Figure $3 \mathrm{~K}$ ) and are interconnected by a parenchyma strip rich in pit-fields (Figure $3 \mathrm{~L}$ ). The vascular bundles are collateral (Figure $3 \mathrm{~J}$ ), surrounded by a thick cap adjacent to the phloem, consisting of septate fibres whose walls are rich in pits and assume metachromasia to TBO (Figure $3 \mathrm{M}, \mathrm{N})$. 

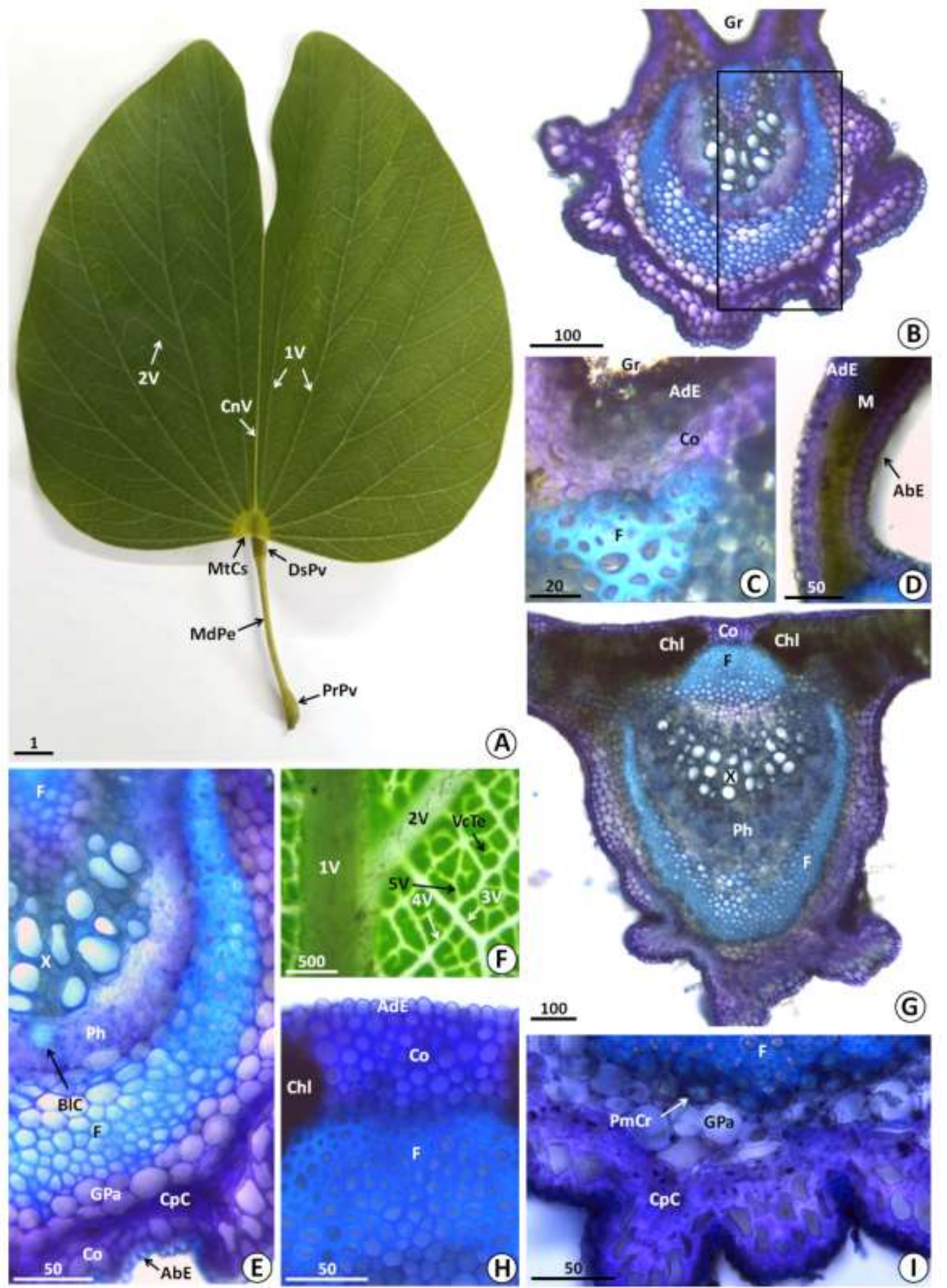

(A)
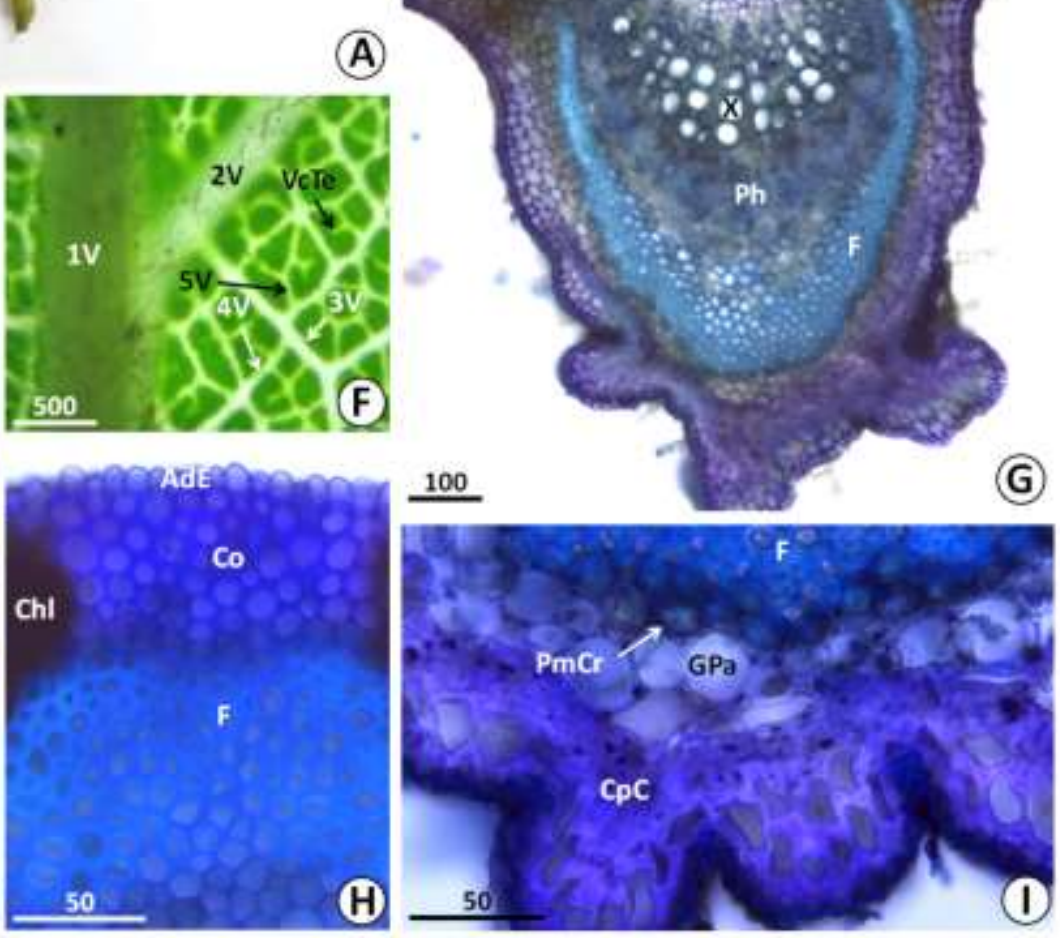

Figure 2. Bauhinia monandra leaf parts and larger veins. A. General view of a whole leaf. B. Cross-section of the central vein. C. Detail of the groove region. D. Detail of the leaf blade adjacent to the central vein. E. Magnification of the region bounded by the rectangle in B. F. Detail of the leaf blade, observed under a stereoscope, with veins of all degrees. G. Cross-section of the first-degree vein. $\mathrm{H}$. Detail of the adaxial part of the vein. I. Detail of the lateral region. Legends: $1 \mathrm{~V}$ - first-degree vein; $2 \mathrm{~V}$ - second-degree vein; 3V- third-degree fein; 4V- fourth-degree vein; 5V-fifth-degree vein; AbEabaxial epidermis; AdE- adaxial epidermis; BIC- blue stained cell; Chl- chlorenchyma; CnV- central vein; Cocollenchyma; CpC-collapsed cells; DsPv- distal pulvinus; F- fibres; GPa- ground parenchyma; Gr- groove; Mmesophyll; $\mathrm{MdPe}$ - medium petiole; MtCs- motile cushion; $\mathrm{Ph}$ - phloem; $\mathrm{PmCr}$ - prismatic crystal; $\mathrm{PrPv}$ - proximal pulvinus; $X-x y l e m$. Scale bars are in centimetres $(A)$ and in micrometres (B-I). 

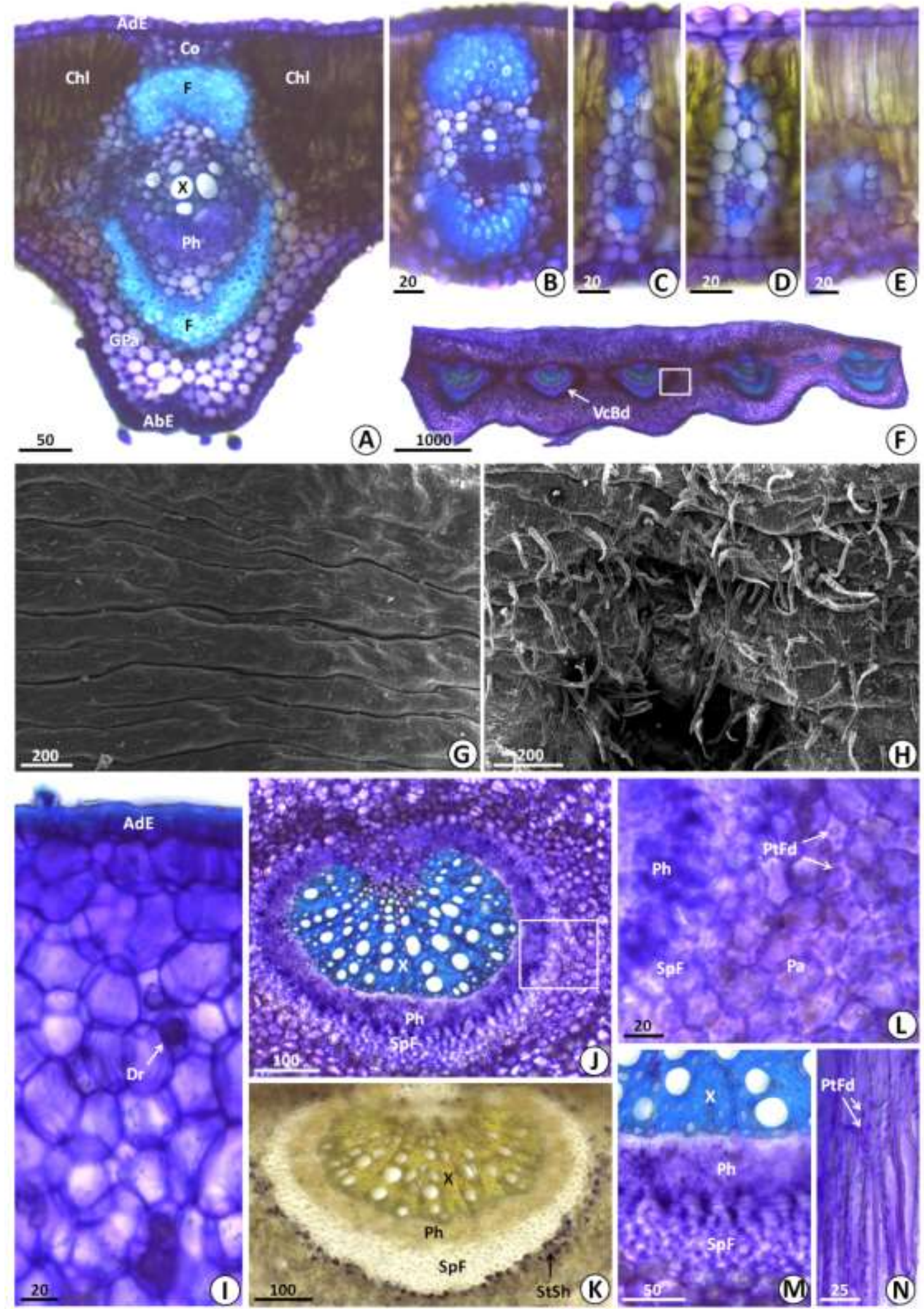

Figure 3. Bauhinia monandra minor leaf veins $(A-E)$ and motile cushion $(F-N)$, under the light microscope $(A-F, I-N)$ and the scanning electron microscope $(G, H)$. A. Second-degree vein. B. Third-degree vein. C. Fourth-degree vein. D. Fifthdegree vein. E. Vascular termination. F. General view of the longitudinal-section of the motile cushion. G. Motile cushion in adaxial view. H. Motile cushion in abaxial view. I. Detail of the adaxial part of the motile cushion. J. Detail of the vascular bundle of the motile cushion. K. Like in J, but stained with Lugol, showing the starch sheath. L. Detail of the parenchyma with pit-fields, between vascular bundles in the motile cushion, according to the region delimited by the rectangles in $\mathrm{F}$ and $\mathrm{J}$. M. Detail of the abaxial part of the vascular bundle. N. Longitudinal-section of the septate fibres of the motile cushion. Legends: AbE- abaxial epidermis; AdE- adaxial epidermis; Chl- chlorenchyma; Co- collenchyma; Dr- druse; F- fibres; GPa- ground parenchyma; Pa- parenchyma; Ph- phloem; PtFd- pit-fields; SpF- septate fibres; StShstarch sheath; VcBd- vascular bundle; X- xylem. Scale bars are in micrometres. 


\section{Petiole}

The distal pulvinus has an elliptical shape in cross-section (Figure 4 A). The epidermis has a layer of ordinary cells whose cuticle corresponds to about half the height of the anticlinal walls (Figure 4 B). Spaced nonglandular trichomes and, eventually, navicular trichomes occur. Subjacent, there is a large parenchyma consisting of large cells (Figure 4 A, B), many of which containing druses. These druse cells occur in a progressively greater quantity towards the four vascular bundles. The parenchymal cells close to vascularisation contain chloroplasts (Figure $4 \mathrm{C}$ ). The vascular bundles are wrapped together by a starch sheath (Figure $4 \mathrm{D}$ ) where some cells may contain druse or prismatic crystal (Figure $4 \mathrm{E}$ ). They are collateral, arranged in two pairs aligned on the longest axis of the organ when in cross-section. Each pair consists of a larger bundle, with the phloem facing the periphery, and a smaller one, with the phloem facing the centre of the organ (Figure $4 \mathrm{~A}$ ). Eventually, prismatic crystals can occur in the phloem (Figure $4 \mathrm{~F}$ ). Externally, involving the vascular bundles set, there is a sheath of septated fibres (Figure $4 \mathrm{G}$ ) with conspicuous pits. These fibres are characterised for assuming metachromasia to TBO (Figure 4 A, F, G), and are also present between the smaller vascular bundles.

The inter-pulvinus portion of the petiole has a sub-elliptical format in cross-section, with a larger dorsiventral axis and flat adaxial side (Figure $4 \mathrm{H}$ ). The epidermis is single-layered, consisting of cells of quadrangular format in both cross and longitudinal-sections. The cuticle is relatively thick (Figure $4 \mathrm{I}$ ). Stomata are absent. Uniseriate nonglandular trichomes are practically non-existent and, even more rarely, navicular trichomes occur. Subjacent two to four layers of annular collenchyma occur (Figure $4 \mathrm{I}, \mathrm{L}$ ) and, internally, about ten layers of chlorenchyma tending to ground parenchyma (Figure $4 \mathrm{~J}$ ). The vascularisation consists of a ring of collateral vascular bundles of varying sizes, where the most abaxial is the largest one and the most adaxial is the second largest. The other vascular bundles are much smaller than those mentioned above. The most adaxial is in an eccentric position, projecting itself between two accessory collateral bundles external to the ring. These bundles form protrusions on the adaxial face of the petiole, resulting in the flattening of this side (Figure $4 \mathrm{H}$ ).

Each of the accessory bundles has a thick cap of fibres associated with the phloem, however without surrounding completely the bundle (Figure $4 \mathrm{~J}$ ). The ring of vascular bundles is completely surrounded by fibres arranged in circa of six layers (Figure $4 \mathrm{H}$ ). Externally, prismatic crystals occur (Figure $4 \mathrm{~K}, \mathrm{~L}$ ). All of these fibres are greenish-blue when stained with TBO (Figure $4 \mathrm{H}$ ). Inside the ring of vascular bundles, there is a large pith with voluminous parenchymal cells, where the most peripheral ones accumulate starch grains. Druses rarely occur (Figure $4 \mathrm{M}$ ).

The proximal pulvinus has a relatively regular circular format when in cross-section (Figure $5 \mathrm{~A}$ ). It is the thickest portion of the petiole (Figure $2 \mathrm{~A}$ ). The epidermis is single-layered, with square cells in cross-section. The thickness of the cuticle is practically the same as the cell lumen. Nonglandular trichomes are rare and navicular ones are practically nonexistent. Subjacent, there is a wide cortex of parenchymal cells (Figure 5 A, B), with a progressively greater number of druses occurring in the vicinity of the vascularisation, which is surrounded by a starch sheath (Figure $5 \mathrm{C}$ ).

In the centre of the proximal pulvinus there is a concentric amphicribral vascular bundle, with a circular, but slightly triangular, shape with the apex facing the adaxial side. The diameter of the vascular bundle corresponds to just over a third of the pulvinus diameter (Figure $5 \mathrm{~A}$ ). In the outer portion of the bundle, septate fibres similar to those observed in the distal pulvinus occur (Figure $5 \mathrm{~A}, \mathrm{C}-\mathrm{E}$ ). The phloem protrudes centripetally at the apex of the rounded triangle, conferring a depression in the xylem in this region and, consequently, a U-shape to the restricted pith parenchyma. On the adaxial side, the vascular tissues are more voluminous (Figure $5 \mathrm{~A}$ ). 


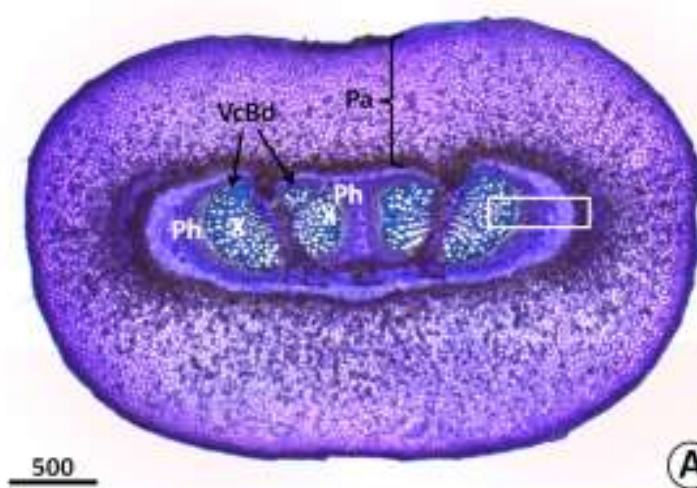

(A)
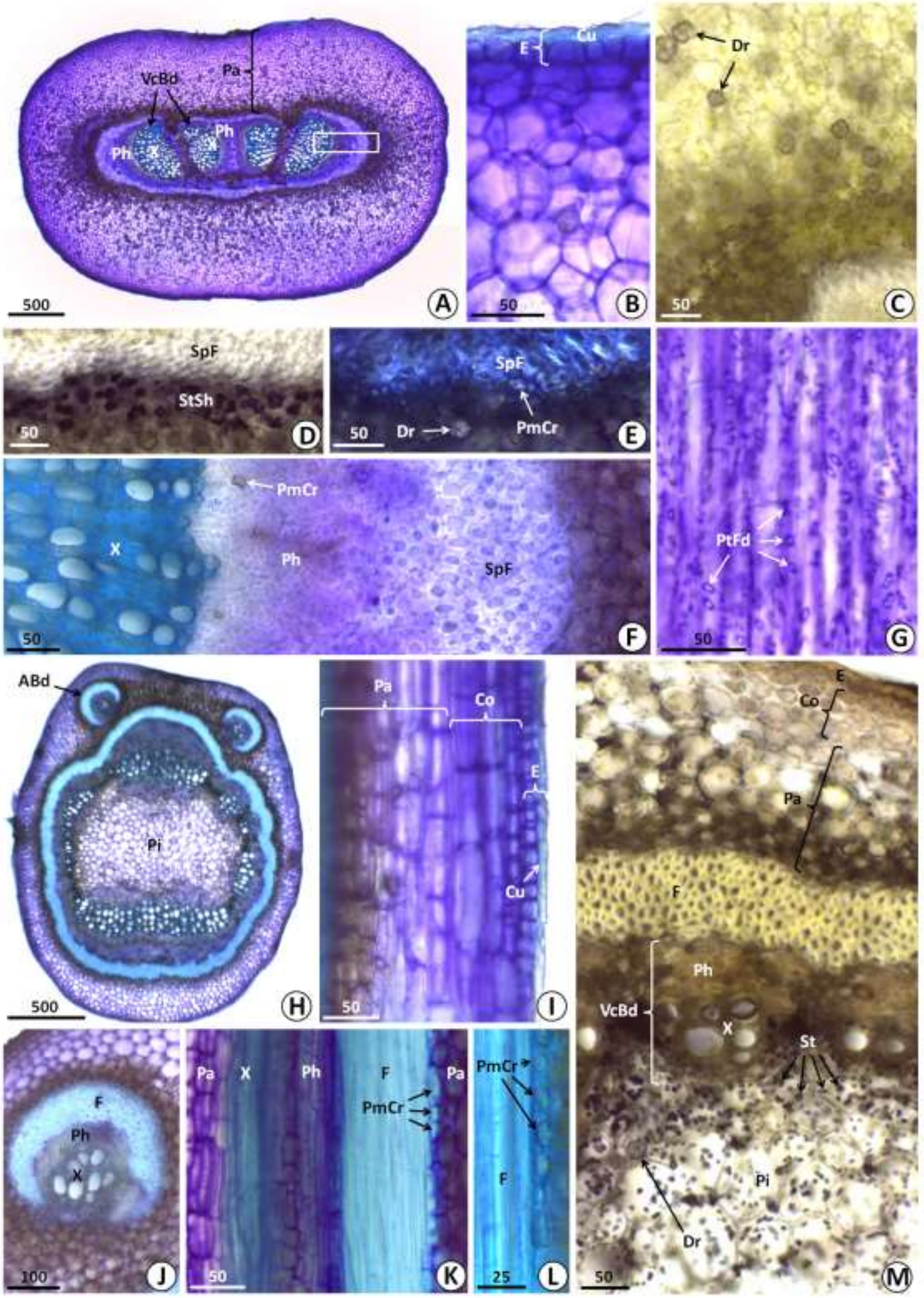

Figure 4. Bauhinia monandra distal pulvinus $(\mathrm{A}-\mathrm{I})$ and petiole middle part $(\mathrm{H}-\mathrm{M})$. A. General view of the distal pulvinus in cross-section. B. Detail of the adaxial portion. C. Detail of the inner region of the cortical parenchyma. D. Detail of the starch sheath adjacent to the septate fibres of the vascular bundles, stained with Lugol. E. Like in D, but stained with Toluidine blue $\mathrm{O}$ pH 4.0. F. Detail of the vascular bundles' tissues, as identified in the rectangle in A. G. Septate fibres in longitudinal-section. H. General view of the cross-section of the petiole middle part. I. Longitudinal-section of the cortical region of the petiole. J. Detail of an accessory vascular bundle. K. Longitudinal-section of a vascular bundle of the vascular ring. L. Detail of fibres in longitudinal-section with prismatic crystals in evidence. M. Detail of all tissues of the petiole middle part in cross-section, stained with Lugol. Legends: ABd-accessory vascular bundle; Co- collenchyma; Cu- cuticle; Dr- druses; E- epidermis; F- fibres; Pa- parenchyma; Ph- phloem; Pi- pith; PmCr- prismatic crystal; PtFdpit-fields; VcBd- vascular bundle; SpF- septate fibres; St- starch grains; StSh- starch sheath; X- xylem. Scale bars are in micrometres. 

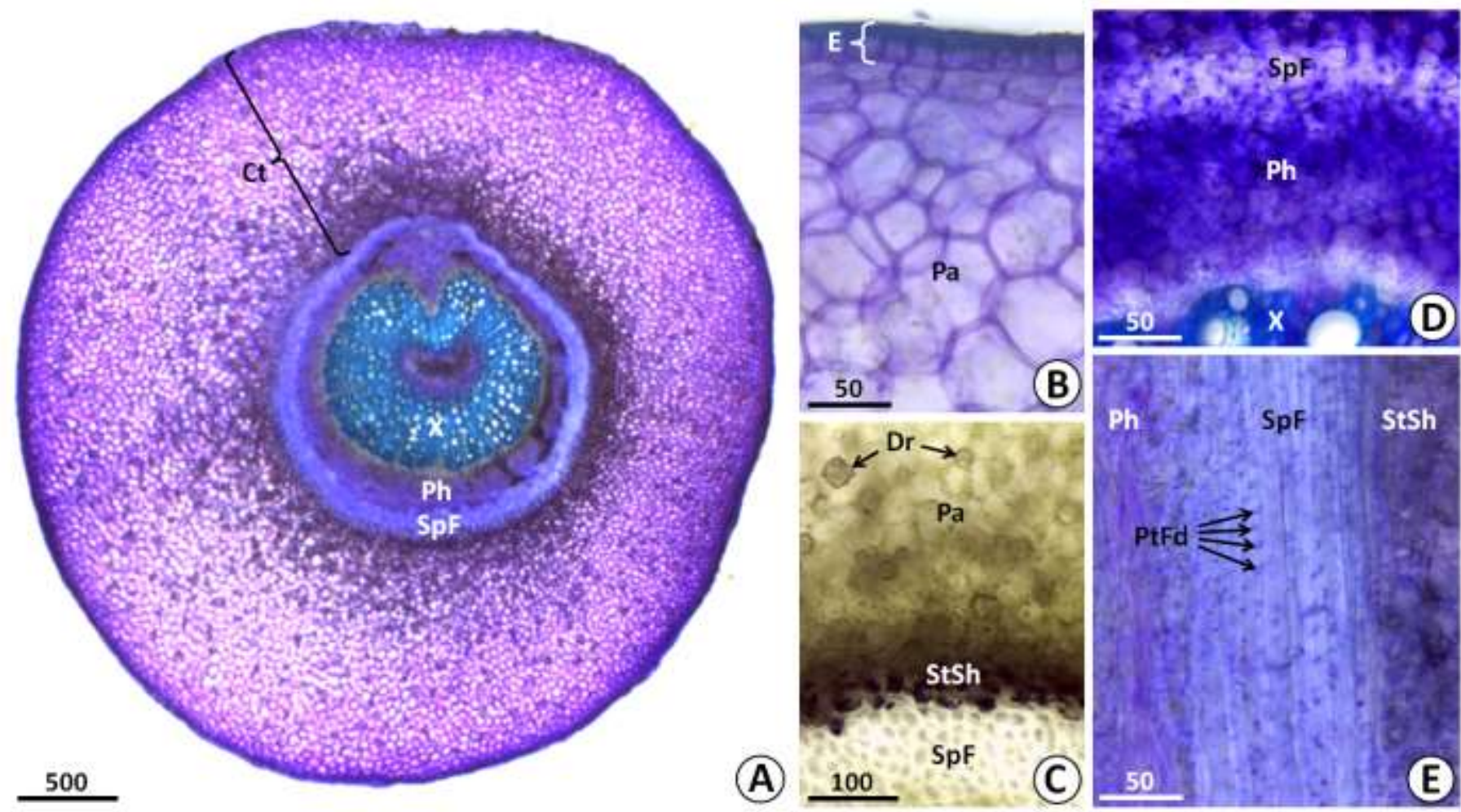

Figure 5. Bauhinia monandra proximal pulvinus. A. General view of the cross-section of the pulvinus. B. Detail of the cortical region. C. Detail of the internal region of the cortex, stained with Lugol for starch contrast. D. Detail of the vascular tissues. E. Longitudinal-section of the region of the septate fibres. Legends: Ct- cortex; Dr- druses; Paparenchyma; Ph- phloem; PtFd- pit-fields; SpF- septate fibres; StSh- starch sheath; X- xylem. Scale bars are in micrometres.

\section{DISCUSSION}

The papillate or subpapillate leaf epidermis is characteristic of Bauhinia [43]. The hypostomatous condition is common for the genus [28,30] and is the one reported for fossil records of several Bauhinia species from the Miocene [47]. However, in the living Bauhinia species, the amphistomatous condition with a higher density of stomata on the abaxial side is generally reported, [24,26,27,31], although $B$. curvula presents an inverse condition, with greater stomatal density on the adaxial epidermis [26]. $B$. monandra is amphistomatous, but stomata on the adaxial side are few and restricted to the immediate vicinity of the larger veins, where the mesophyll is thicker. A similar condition is described in B. forficata [29]. However, in $B$. monandra the adaxial stomata have a rudimentary aspect which suggests little functionality and, in this case, it can be inferred that this species is physiologically hypostomatous.

The stomata described for the genus are of the paracytic, anisocytic, tetracytic, and anomocytic type, corroborating with the paracytic and anomocytic types observed in $B$. monandra in the present work, similarly to $B$. blakeana [23] and B. curvula [26]. It is possible that, from the paracytic, described for fossil records of Bauhinia from the Miocene [47], it has derived into the other stomata types of the genus.

The plate pattern of the epicuticular waxes observed in $B$. monandra is similar to that illustrated for $B$. forficata and $B$. variegata, however, a notable higher density was not observed on the abaxial epidermis, as reported for these two species [29]. On the contrary, in $B$. monandra a slightly more coarse appearance of the epicuticular waxes was noted in the adaxial epidermis.

Uni to pluricellular, normal (non-branched) uniseriate trichomes are typical for the Bauhinia genus. They are usually pluricellular, although, in B. microstachya [30], B. racemosa and B. tomentosa [24] unicellular trichomes are exclusively reported. The verrucous cuticle of these trichomes was emphasised only in the description of $B$. microstachya [30], a condition similar to that of $B$. monandra. The glandular trichomes are also characteristic for the genus. It is generally described in the petiole and the abaxial side of the leaf blade in other Bauhinia species, in agreement with that observed in B. monandra. In B. forficata, alkaloids, glycides and lipid droplets were found to occur in these trichomes [28]. However, there are no reports on this type of trichome in anatomical leaf studies for several species of the genus [30,31]. 
The straight to sinuous anticlinal walls of the ordinary epidermal cells of the leaf blade is typical for the genus, and both sides may or may not have the same pattern. Apparently, straight anticlinal walls are the most common type $[24,31]$. In $B$. monandra, sinuous to straight walls in the adaxial epidermis and straight walls in the abaxial one can be a strong diagnosis, since no reports of this pattern were found in the bibliographic survey carried out for any other species of the genus. Some epidermal features of the leaf blade of different species of Bauhinia are organised, comparatively, in Table 1.

In descriptions of the mesophyll for the Bauhinia genus, patterns of chlorenchyma consisting of elongated cells are common, as in B. curvula [26], B. forficata [27, 28] and B. ungulata, and also in the related genus Schnella. In these last two species, the spongy parenchyma constitutes the largest thickness of the mesophyll, and its cells delimit remarkably large intercellular spaces [25]. In B. monandra, although the cells of the spongy parenchyma cells are somewhat elongated, they are shorter than those of the palisade one and in a relatively compact layout, similar to the illustrations in the descriptions for $B$. forficata [29] and $B$. pentandra [25]. Although in most reports for Bauhinia the mesophyll is dorsiventral, in $B$. forficata the mesophyll was described as homogeneous [27] and isobilateral [28]. This disagreement may be due to differences in interpretation among the authors or by phenotypic differences between the studied individuals.

The leaf margin has special potential for taxonomic application in Bauhinia, as it provides distinctive anatomical characteristics between species of the genus [25]. Nevertheless, due caution is necessary, as environmental factors can result in small anatomical variations in the leaf margin of the same species, as reported in $B$. forficata [28]. Unfortunately, little emphasis is given to the leaf margin in anatomical descriptions for the genus. Like $B$. forficata and $B$. variegata [29], $B$. monandra has a vascular bundle on the margin resulting in its dilatation. The more rounded condition of this vascular bundle also coincides with that illustrated in the work of Lusa and Bona [29]. The presence of what appears to be a parenchymatous hypodermis with one to three cell layers observed in $B$. monandra is, apparently, a characteristic that deserves attention. It is important to note that ontogenetic studies are necessary to confirm whether this tissue is, in fact, an actual hypodermis.

The lesser thickness of the mesophyll observed in the vicinity of the central vein of $B$. monandra is also visible in the illustrations of the anatomical descriptions of the other species of Bauhinia [23, 25, 26, 28, 29]. This narrowing was mentioned only in the work on $B$. forficata [28], but in a superficial way. This is probably a condition found in all species of the genus, being an adaptation for the greater flexibility of the leaf blade in the nastic movements of leaf opening and closing.

All B. monandra leaf veins, including the fifth-degree ones, extend from epidermis-to-epidermis, interrupting the continuity of the mesophyll chlorenchyma. Thus, the leaf blade is a mosaic of chlorenchyma compartments delimited by areoles, which restrict the free lateral gases movement along the mesophyll. Leaves like this are called heterobaric [48]. Some features of leaf blade of different species of Bauhinia are organised, comparatively, in Table 2.

The cross-section of the $B$. monandra petiole middle part demonstrated a remarkable feature at first sight: the absence of lateral projections on the adaxial side. These projections, which are subtended by the two accessory collateral bundles, are reported in most leaf anatomical descriptions for the genus, causing the petiole adaxial face to have the greatest width. In $B$. monandra, the largest vascular bundle width is found on its middle portion. A similar condition is reported for $B$. microsthachya, however, this species vary in not having accessory bundles [30]. Some Bauhinia species have a vascular bundle in a central position, surrounded by the ring of non-accessory vascular bundles, such as $B$. cheilantha [25] and B. curvula [26]. B. blakeana has the unusual characteristic of having one or two accessory collateral vascular bundles and about eight bicollateral bundles distributed in the central region, apparently without delimiting a ring [23]. A common condition is that ring vascularisation forms a projection towards its central part, as reported for $B$. forficata [27], $B$. microstachya [30] and $B$. pentandra and, in an extreme case, the separation into two large amphicribral bundles in $B$. ungulata [25]. B. monandra has the vascular bundles situated in a circular arrangement, forming a projection towards the cortex, between the two adaxial accessory bundles, being another remarkable differential for the species. This variety of forms indicates a great taxonomic potential for the petiole anatomy in Bauhinia.

The $B$. monandra pulvinus follows the general pattern described for Fabaceae, with a wide cortex, vascularisation in a central position and a restricted or absent of pith [25, 28, 29, 49-51]. A starch sheath was found in both $B$. monandra pulvinus, which also occurs around the motile cushion bundles. Interestingly, in the inter-pulvinus petiole, this sheath is absent, with amyloplasts occurring only in the cells of the pith parenchyma, similar to the condition described for $B$. forficata e $B$. variegata [29]. Unfortunately, little attention 
is paid to the starch sheath in the reports of leaf anatomy in Bauhinia, although the Lugol test [38], for starch detection, is extremely simple.

The appearance of the proximal pulvinus of $B$. monandra is practically identical to that reported for $B$. forficata [29], as it presents a single large amphicribral concentric vascular bundle delimiting a small pith, with a vascular projection on the adaxial side directed to the centre. B. pentandra also has the same pattern according to the illustration of Pereira et al. [25] work, although the authors classified the vascular bundle as of bicollateral type.

The distal pulvinus of $B$. monandra has the vascular arrangement typical to all the few reports found for the genus, with two pairs of collateral bundles, where the largest ones are peripheral with the phloem facing the cortex, and the two central ones are smaller vascular bundles with the phloem facing the centre [25, 26, $28,29]$. As it is a transitional structure between the inter-pulvinus petiole and the motile cushion, some variation can be found depending on the level of the section in the same pulvinus, which requires some caution in using the vascular aspects of this structure for taxonomic purposes.

The ripples observed in the epidermis pulvinus in legumes are related to their ability to move [50]. Similar ripples have been reported in Bauhinia species [29] and also observed in the $B$. monandra pulvinus and motile cushion in the present work, with them certainly being related to the wide flexing movements of these structures. The rich plasmodesmata connection between parenchymal cells that interconnect the vascular bundles in the motile cushion is also reported in $B$. curvula [39] and it may be related to the physiological processes for the movements of this structure.

The pectic nature of the septate fibres walls in the pulvinus of $B$. monandra, verified by the metachromasia to TBO, as well as the lignified nature of the petiole's rigid fibres, by the bluish colouration conferred by this same dye [38], corroborates with the reported for $B$. curvula [26]. Likewise, the bluish colouration conferred by this dye for the fibres of $B$. monandra leaf blade veins also indicates their lignified nature [38]. In the primary and secondary pulvinus of Pterodon pubescens, septate fibres similar to those observed in $B$. monandra are described as pericyclic [49] and, by analogy, it can be deduced that the septate fibres of the $B$. monandra pulvinus have this same origin. The pits and the lack of lignification guarantee, respectively, symplastic and apoplastic continuity between pith and cortex $[49,51,52]$ within the latter there are the motor cells [53] responsible for pulvinus movement. There are also similar septate fibres external to the phloem of the vascular bundles of the $B$. monandra motile cushion, which allows inferring the same pericyclic origin and the similar flexibility and physiological functions in this motor structure continuous to the distal pulvinus. The rich impregnation of pectates in the walls of these fibres define them as gelatinous fibres.

The occurrence of phenolic compounds is common in pulvinus, being reported in the phloem, pith, and cortex in several legume species $[49,50]$. The dye used in the present work, TBO, indicated the presence of this chemical class only in some mesophyll and hypodermis cells, as well as in the phloem of the central vein of the $B$. monandra leaf. Nevertheless, no phenolic cells were seen in the pulvinus or motile cushion. This dye provides a typical bluish or greenish-blue colouration to phenolic compounds [38], however, it is not a specific histochemical test and, therefore, the results on phenols presented here are only inferences, requiring verification by further studies.

The sclerenchyma and crystal sheath involving the vascularisation of the middle petiole is a characteristic reported in all work on Bauhinia in the bibliographic survey carried out. In the leaf vein sheath, prismatic crystals are reported $[23,36]$, corroborating the condition observed in $B$. monandra. Druses are also reported in the mesophyll of several Bauhinia species [25,29,36], and mainly in the pulvinus cortex and/or motile cushion $[25,26,28,29]$. The accumulation of calcium oxalate crystals in photosynthetic organs is a normal phenomenon that is linked to plant metabolism [54]. These substances are forms of calcium storage [55] in response to its excess [56-59], and can be a repository with high capacity for this ion [60]. Since the movements performed by the pulvinus are the result of osmotic phenomena where $\mathrm{Ca}^{2+}$ acts $[61,62]$, and considering that the motile cushion is a structure physiologically similar to the pulvinus, the rich presence of druses in the cortex of these motor structures may be related to the local availability of this ion. Also, calcium oxalate crystals are considered to be feeding deterrents, preventing herbivory [63]. 
Table 1. Anatomical features of the leaf blade epidermis of different species of Bauhinia.

NR - Not reported.

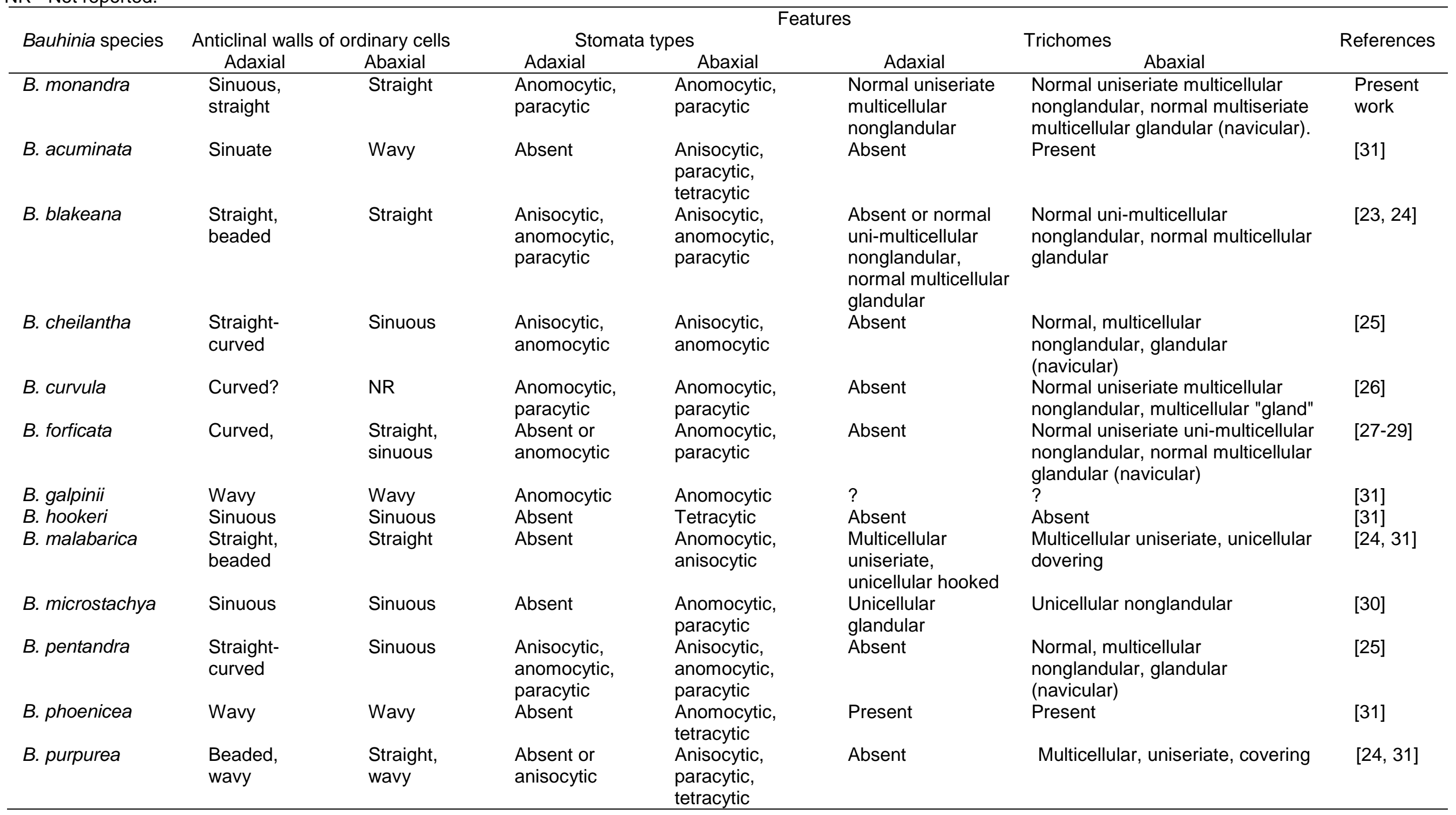


Cont. Table 01

\begin{tabular}{|c|c|c|c|c|c|c|c|}
\hline \multirow{3}{*}{ Bauhinia species } & \multicolumn{7}{|c|}{ Features } \\
\hline & \multicolumn{2}{|c|}{ Anticlinal walls of ordinary cells } & \multicolumn{2}{|c|}{ Stomata types } & \multicolumn{2}{|c|}{ Trichomes } & \multirow[t]{2}{*}{ References } \\
\hline & Adaxial & Abaxial & Adaxial & Abaxial & Adaxial & Abaxial & \\
\hline B. racemosa & Straight & Straight & $\begin{array}{l}\text { Absent or } \\
\text { tetracytic }\end{array}$ & $\begin{array}{l}\text { Anisocytic, } \\
\text { anomocytic,p } \\
\text { aracytic }\end{array}$ & $\begin{array}{l}\text { Absent or normal } \\
\text { uniseriate uni- } \\
\text { multicellular } \\
\text { nonglandular }\end{array}$ & $\begin{array}{l}\text { Normal uniseriate uni- } \\
\text { multicellular glandular }\end{array}$ & {$[24,31]$} \\
\hline B. rufescens & Straight & Straight & $\begin{array}{l}\text { Anisocytic, } \\
\text { anomocytic }\end{array}$ & Tetracytic & $?$ & $?$ & [31] \\
\hline B. tomentosa & Undulated & Undulated & $\begin{array}{l}\text { Absent or } \\
\text { tetracytic }\end{array}$ & $\begin{array}{l}\text { Anisocytic, } \\
\text { paracytic, } \\
\text { tetracytic }\end{array}$ & $\begin{array}{l}\text { Unicellular } \\
\text { nonglandular }\end{array}$ & Unicellular nonglandular & {$[24,31]$} \\
\hline B. ungulata & $\begin{array}{l}\text { Straight- } \\
\text { curved }\end{array}$ & Curved & $\begin{array}{l}\text { Anisocytic, } \\
\text { anomocytic, } \\
\text { paracytic }\end{array}$ & $\begin{array}{l}\text { Anisocytic, } \\
\text { anomocytic, } \\
\text { paracytic }\end{array}$ & Nonglandular & $\begin{array}{l}\text { Normal, multicellular } \\
\text { nonglandular, glandular } \\
\text { (navicular) }\end{array}$ & [25] \\
\hline B. variegata & Curved & Straight & $\begin{array}{l}\text { Anisocytic, } \\
\text { anomocytic }\end{array}$ & $\begin{array}{l}\text { Anisocytic, } \\
\text { anomocytic, } \\
\text { paracytic, } \\
\text { tetracytic }\end{array}$ & $\begin{array}{l}\text { Normal uniseriate } \\
\text { uni-multicellular } \\
\text { nonglandular, } \\
\text { normal multicellular } \\
\text { glandular (navicular) }\end{array}$ & $\begin{array}{l}\text { Normal, uniseriate uni- } \\
\text { multicellular nonglandular, } \\
\text { normal multicellular } \\
\text { glandular (navicular) }\end{array}$ & {$[29,31]$} \\
\hline
\end{tabular}

Table 2. Anatomical feature of the mesophyll and leaf margin of different species of Bauhinia.NR - Not reported.

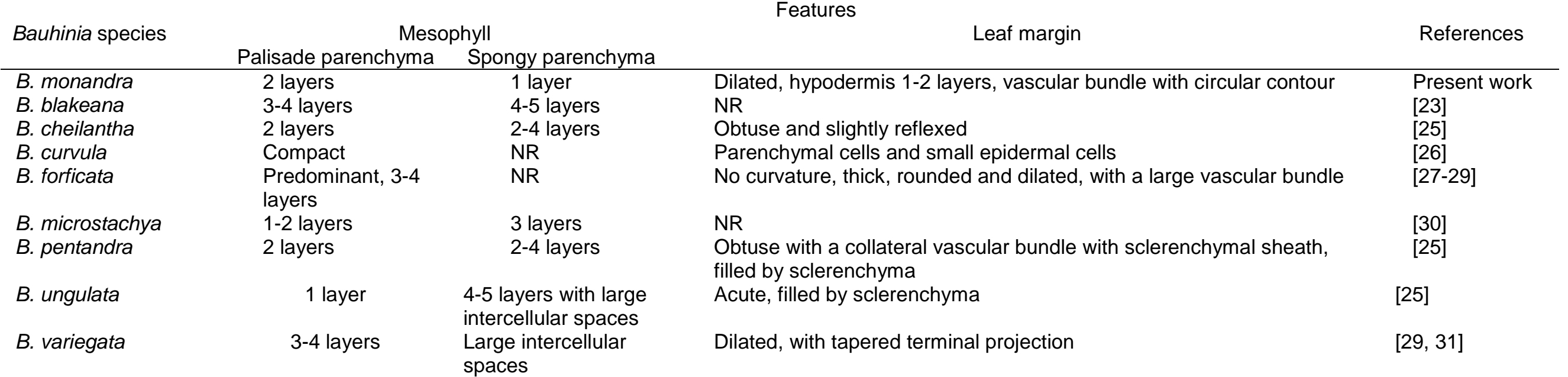




\section{CONCLUSION}

It was observed that the $B$. monandra leaf shares common anatomical characteristics described for other species of the genus. However, the analysis of diverse structural parameters showed distinctive aspects in relation to the reports of other species of Bauhinia available in the literature. It is worth mentioning that the petiole was structurally more different compared to reports from other Bauhinia species because it did not have lateral projections and because of the ring of vascular bundles protruding between the accessory bundles. The leaf of $B$. monandra exhibits mesomorphous to xeromorphous characteristics and is, apparently, little pubescent, in comparison to most reports found on the genus.

Funding: This research received no external funding.

Acknowledgments: We thank Prof. PhD Claudenir Simões Caires, from the Department of Natural Sciences of State University of Southwest Bahia, for the identification of the species; Prof. PhD Delmira da Costa Silva, from the Department of Biological Sciences, and MSc Lucas Ribeiro, from the Center of Electronic Microscopy of State University of Santa Cruz, Ilhéus, Bahia, Brazil, for the support in the electron microscopy procedures; and biologist Valdir Carvalho Ribeiro, for revising the English translation of the manuscript.

Conflicts of Interest: The authors declare no conflict of interest.

\section{REFERENCES}

1. LPWG. A new subfamily classification of the Leguminosae based on a taxonomically comprehensive phylogeny. Taxon. 2017;66(1):44-77.

2. Lewis GP. Legumes of Bahia. London: Royal Botanic Gardens; 1987.

3. Van der Pijl L. The leaf of Bauhinia. Acta Bot Neerland. 1952;1(2):287-309.

4. Gupta AK, Vidyapati TJ, Chauhan JS. Chemical examination of the stem of Bauhinia divaricata. Planta Med. 1980;38:174-6.

5. Menezes FS, Minto ABM, Ruela HS, Kuster RM, Sheridan H, Frankish N. Hypoglycemic activity of two Brazilian Bauhinia species: Bauhinia forficata L. and Bauhinia monandra Kurz. Braz J Pharmacogn. 2007;17(1):8-13.

6. Gonzalez-Mujica F, Motta N, Márquez AH, Capote-Zulueta J. Effects of Bauhinia megalandra aqueous leaf extract on intestinal glucose absorption and uptake by enterocyte brush border membrane vesicles. Fitoterapia. 2003;74:84-90.

7. Alade GO, Omobuwajo OR, Adebajo CA, Versopohl EJ. Evaluation of the hypoglycaemic activity of Bauhinia monandra leaf in Alloxan-diabect rats and INS-1 inulin cells. J Chem Pharm Res. 2011;3(2):506-21.

8. Sinou C, Forest F, Lewis GP, Bruneau A. The genus Bauhinia s.l. (Leguminosae): a phylogeny based on the plastid trnL-trnF region. Botany. 2009;87(10):947-60.

9. Lorenzi H. Árvores exóticas no Brasil: madeireiras, ornamentais e aromáticas. Rio de Janeiro: Ed. Plantarum; 2003.

10. Könemann. Botanica: the illustrated $A-Z$ of over 10,000 garden plants and how to cultivate them. 3th ed. Sydney: Random House Australia Pty Ltd.; 2004.

11. Duryea ML, Kampf E, Littell RC, Rodríguez-Pedraza CD. Hurricanes and the urban forest: II. Effects on tropical and subtropical tree species. Arboric Urban For. 2007;33(2):98-112.

12. Araújo AC, Ribeiro IAM, Morais MS, Araújo JLO. Análise quali-quantitativa da arborização no bairro Presidente Médici, Campina Grande-PB. Revsbau. 2009;4(1):133-44.

13. Silva RN, Gomes MAS. Quali-quantitative comparison of arborization in public spaces of the city of Arapiraca-AL, Brazil. REVSBAU. 2013;8(2):104-17.

14. Akintunde AM, Ojala SO, Betiku E. Optimization of Bauhinia monandra seed oil extraction via artificial neural network and response surface methodology: a potential biofuel candidate. Ind Crop Prod. 2015;67:387-94.

15. Anhwange BA, Ajibola VO, Oniye SJ. Amino acid compositon of the seeds of Moringa oleifera (Lam), Detarium microcarpum (Guill \& Sperr) and Bauhinia monandra (Linn.). Chemclass J. 2004;(9-13).

16. Argolo ACC, Dantas VCR, Saturnino ACRD, Santos AFS, Brandão-Neto J, Paixão ADO, Coelho LCBB. Leaf ethanolic extract of Bauhinia monandra increases insulin secretion in rats subjected to intrauterine malnutrition. Int J Biochem Res Rev. 2015;9(4):1-9.

17. Ajiboye AT, Musa MD, Otum KO, Jimoh AA, Bale AT, Lawal SO, Arowona MT. The studies of antioxidant and antimicrobial potentials of the leaf extract of Bauhinia monandra plant. Nat Prod Chem Res. 2015;3(4):1000180.

18. Argolo ACC, Sant'Ana AEG, Pletsch M, Coelho LCBB. Antioxidant activity of leaf extracts from Bauhinia monandra. Bioresour Technol. 2004;95:229-233. 
19. Aderogba MA, Ogundaini AO, Eloff JN. Isolation of two flavonoids from Bauhinia monandra (Kurz) leaves and their antioxidative effects. Afr J Trad CAM. 2006;3(4):59-65.

20. Nworie KM, Okorie NA. Phytochemicals distribution and antioxidant potential of Bauhinia monandra (Linn.) leaves extract. Res J Med Plants. 2018;12(2):78-83.

21. Campos JKL, Araújo CSF, Araújo TFS, Santos AFD, Teixeira JA, Lima VLM, Coelho LCBB. Anti-inflammatory and antinociceptive activities of Bauhinia monandra leaf lectin. Biochim Open. 2016;2:62-8.

22. Macedo MLR, Freire MGM, Silva MBR, Coelho LCBB. Insecticidal action of Bauhinia monandra leaf lectin (BmoLL) against Anagasta kuehniella (Lepidoptera: Pyralidae), Zabrotes subfasciatus and Callosobruchus maculatus (Coleoptera: Bruchidae). Comp Biochem Physiol A Mol Integr Physiol. 2007;146:486-98.

23. Ferreira JLP, Velasco E, Paula AES, Araújo RB, Pacheco JM. Anatomia foliar de Bauhina blakeana Dunn. Rev Bras Farmacogn. 2003;13 Suppl.:11-14.

24. Albert S, Sharma B. Comparative foliar micromorphological studies of some Bauhinia (Leguminosae) species. Turk J Bot. 2013;37:276-81.

25. Pereira LBS, Costa-Silva R, Felix LP, Agra MF. Leaf morphoanatomy of "mororó" (Bauhinia and Schnella, Fabaceae). Rev Bras Farmacogn. 2018;28:383-92.

26. Rezende MH, Cardoso LA, Vannucci AL. Morphology and anatomy of Bauhinia curvula Benth. (LeguminosaeCaesalpinioideae). Acta Bot Bras. 1994;8(1):19-34.

27. Miyake ET, Akisue G, Akisue MK. Pharmacognostic characterization of pata-de-vaca Bauhinia forficata Link. Rev Bras Farmacogn. 1986;1:58-68.

28. Donato AM. Anatomia foliar e abordagem fitoquímica de Bauhinia forficata Link. (Leg-Caes). Bradea. 1995;6(42):357-71.

29. Lusa MG, Bona C. Comparative morphological and anatomical analyses of Bauhinia forficata Link and B. variegata Linn. (Leguminosae, Caesalpinioideae). Acta Bot Bras. 2009;23(1):196-211.

30. Duarte MR, Debur MC. Caracteres morfo-anatômicos de folha e caule de Bauhinia microstachya (Raddi) J. F. Macbr (Fabaceae). Rev Bras Farmacogn. 2003;13(1):7-15.

31. Kotresha K, Seetharam YN. Epidermal studies in some species of Bauhinia L. (Caesalpinioideae). Phytomorphology. 1995;45(1-2):127-37.

32. Janaćković P, Gavrilović M, Rančić D, Dajić-Stevanović Z, Giweli AA, Marin PD. Comparative anatomical investigation of five Artemisia L. (Anthemideae, Asteraceae) species in view of taxonomy. Braz $\mathrm{J}$ Bot. 2019;42(1):135-47.

33. Kolb KL, Gomes SMA, Lombardi JA. Leaf anatomy as a taxonomy tool for the identification of Brazilian native species of Chionanthus (Oleaceae). Flora. 2020;266:151590.

34. Engel IC, Ferreira RA, Cechinel-Filho V, Meyre-Silva C. Controle de qualidade de drogas vegetais a base de Bauhinia forficata Link (Fabaceae). Rev Bras Farmacogn. 2008;18(2):258-64.

35. Bochner R, Fiszon JT, Assis MA, Avelar KES. Problemas associados ao uso de plantas medicinais comercializadas no Mercadão de Madureira, município do Rio de Janeiro, Brasil. Rev Bras PI Med. 2012;14(3):537-47.

36. Fortunato $\mathrm{RH}$, Varela $\mathrm{BG}$, Castro MA, Nores MJ. Leaf venation pattern to recognize austral South American medicinal species of "cow's hoof' (Bauhinia L. Fabaceae). Rev Bras Farmacogn. 2017;27:158-61.

37. Vidal BC. Acid glycosaminoglycans and endochondral ossification: microespectrophotometric evaluation and macromolecular orientation. Cell Mol Biol. 1977;22:45-64.

38. Ribeiro VC, Leitão CAE. Utilisation of Toluidine blue O pH 4.0 and histochemical inferences in plant sections obtained by free-hand. Protoplasma. 2020;257:993-1008.

39. Kraus JE, Arduin M. Manual básico de métodos em morfologia vegetal. Seropédica: EDUR; 1997.

40. O'Brien TP, Feder N, McCully ME. Polychromatic staining of plant cell walls by Toluidine blue O. Protoplasma. 1964;59:368-73.

41. Foster AS. Pratical plant anatomy. Princeton: D; van Nostrand Co. Inc.; 1949.

42. Johansen DA. Plant microtechnique. New York: McGraw-Hill Book Co. Inc.; 1940.

43. Metcalfe CR, Chalk L. Anatomy of the dicotyledons. Oxford: Clarendon Press; 1957.

44. Wilkinson HP. The plant surface (mainly leaf). In: Metcalfe CR, Chalk L, editors. Anatomy of the dicotyledons, Volume I. 2nd ed. Oxford: Clarendon Press; 1988. p. 97-165.

45. Karnovsky MJ. A formaldehyde-glutaraldehyde fixative of high osmolality for use in electron microscopy. J Cell Biol. 1965;27:137-8.

46. Bozzola JJ, Russel LD. Electron microscopy. Boston: Jones and Bartlett Publishers; 1992.

47. Lin Y, Wong WO, Shi G, Shen S, Li Z. Bilobate leaves of Bauhinia (Leguminosae, Caesalpinioideae, Cercideae) from the middle Miocene of Fujian Province, southeastern China and their biogeographic implications. BMC Evol Biol. 2015;15:252. 
48. Beerling DJ, Chaloner WG, Huntley B, Pearson JA, Tooley MJ. Stomatal density responds to the glacial cycle of environmental change. Proc R Soc Lond. 1993;251:133-8.

49. Rodrigues TM, Machado SR. Comparative anatomy of pulvinus, petiole and rachis of Pterodon pubescens Benth. (Fabaceae - Faboideae). Acta Bot Bras. 2004;18(2):318-90.

50. Rodrigues TM, Machado SR. Primary pulvinus comparative anatomy of leguminous species with different leaf movement velocity. Revista Bras Bot. 2006;29(4):709-20.

51. Rodrigues TM, Machado SR. Pulvinus funtional traits in relation to leaf movements: a light and transmission electron microscopy study of the vascular system. Micron. 2008;39:7-16.

52. Machado SR, Rodrigues TM. Anatomia e ultra-estrutura do pulvino primário de Pterodon pubescens Benth. (Fabaceae - Faboideae). Revista Brasil Bot. 2004;27(1):135-47.

53. Toriyama H. Observational and experimental studies of sensitive plants, I. The structure of parenchymatous cells of pulvinus. Cytologia. 1953;18:283-92.

54. Francheschi VR, Nakata PA. Calcium oxalate in plants: formation and function. Annu Rev Plant Biol. 2005;56:4171.

55. Ilarslan H, Plamer R, Imsande J, Horner H. Quantitative determination of calcium oxalate and oxalate in developing seeds of soybean (Leguminosae). Am J Bot. 1997;84(8):1042-6.

56. Borchert R. Calcium-induced patterns of calcium-oxalate crystals in isolated leaflets of Gleditsia triacanthos $\mathrm{L}$. and Albizia julibrissin Durazz. Planta. 1985;165:301-10.

57. Borchert R. Caicium acetate induces calcium uptake and formation of calcium-oxalate crystals in isolated leaflets of Gleditsia triacanthos L. Planta. 1986;168:571-8.

58. Franchesci VR. Calcium oxalate formation is a rapid and reversible process in Lemna minor L. Protoplasma. 1989;148(2-3):130-7.

59. Fink S. The micromorphological distribution of bound calcium in needles of Norway spruce [Picea abies (L.) Karst.]. New Phytol. 1991;119:33-40.

60. Zindler-Frank E. Oxalate biosynthesis in relation to photosynthetic pathway and plant productivity - a survey. Z Pflanzenphysiol. 1976;80(1):1-13.

61. Toriyama H, Jaffe MJ. Migration of calcium and its role in the regulation of seismonasty in the motor cell of Mimosa pudica L. Plant Physiol. 1972;49:72-81.

62. Moysset L, Simón E. Secondary pulvinus of Robina pseudoacacia (Leguminosae): structural and ultrastructural features. Am J Bot. 1991;78(11):1467-86.

63. Molano-Flores B. Herbivory and calcium concentrations affect calcium oxalate crystal formation in leaves of Sida (Malvaceae). Ann Bot. 2001;88(3):387-91.

2021 by the authors. Submitted for possible open access publication under the terms and conditions of the Creative Commons Attribution (CC BY NC) license (https://creativecommons.org/licenses/by-nc/4.0/). 